\title{
Somatic Mutation
}

National Cancer Institute

\section{Source}

National Cancer Institute. Somatic Mutation. NCI Thesaurus. Code C18060.

Any mutation with an orig in in cells that are not destined to become gametes. As a consequence, such mutations are not transmitted to progeny, though they will be transmitted during any mitosis within the individual. Somatic mutations may contribute to a broad variety of pathologies including cancer. 